\title{
Emissions of biogenic volatile organic compounds and subsequent formation of secondary organic aerosols in a Larix kaempferi forest
}

\author{
T. Mochizuki ${ }^{1 \text {,a }}$, Y. Miyazaki ${ }^{2}$, K. Ono ${ }^{2}$, R. Wada ${ }^{3}$, Y. Takahashi ${ }^{4}$, N. Saigusa ${ }^{4}$, K. Kawamura ${ }^{2}$, and A. Tani ${ }^{1}$ \\ ${ }^{1}$ Graduate Division of Nutritional and Environmental Sciences, University of Shizuoka, Shizuoka, 422-8526, Japan \\ ${ }^{2}$ Institute of Low Temperature Science, Hokkaido University, Hokkaido, 060-0819, Japan \\ ${ }^{3}$ Department of Natural and Environmental Science, Teikyo University of Science, Yamanashi, 409-0193, Japan \\ ${ }^{4}$ National Institute for Environmental Studies, Ibaraki, 305-8506, Japan \\ ${ }^{a}$ now at: Institute of Low Temperature Science, Hokkaido University, Hokkaido, Japan
}

Correspondence to: A. Tani (atani@u-shizuoka-ken.ac.jp) and Y. Miyazaki (yuzom@lowtem.hokudai.ac.jp)

Received: 20 March 2015 - Published in Atmos. Chem. Phys. Discuss.: 14 April 2015

Revised: 25 September 2015 - Accepted: 11 October 2015 - Published: 29 October 2015

\begin{abstract}
We conducted simultaneous measurements of concentrations and above-canopy fluxes of isoprene and $\alpha$ pinene, along with their oxidation products in aerosols in a Larix kaempferi (Japanese larch) forest in summer 2012. Vertical profiles of isoprene showed the maximum concentration near the forest floor with a peak around noon, whereas oxidation products of isoprene, i.e., methacrolein (MACR) and methyl vinyl ketone (MVK), showed higher concentrations near the canopy level of the forest. The vertical profile suggests large emissions of isoprene near the forest floor, likely due to Dryopteris crassirhizoma (a fern species), and the subsequent reaction within the canopy. The concentrations of $\alpha$ pinene also showed highest values near the forest floor, with maximums in the early morning and late afternoon. The vertical profiles of $\alpha$-pinene suggest its large emissions from soil and litter in addition to emissions from L. kaempferi leaves at the forest site. Isoprene and its oxidation products in aerosols exhibited similar diurnal variations within the forest canopy, providing evidence of secondary organic aerosol (SOA) formation via oxidation of isoprene most likely emitted from the forest floor. Although high abundance of $\alpha$ pinene was observed in the morning, its oxidation products in aerosols showed peaks in daytime, due to a time lag between the emission and atmospheric reactions of $\alpha$-pinene to form SOA. Positive matrix factorization (PMF) analysis indicated that anthropogenic influence is the most important factor contributing to the elevated concentrations of molecular oxidation products of isoprene- ( $>64 \%$ ) and $\alpha$-pinenederived SOA $(>57 \%)$. The combination of the measured
\end{abstract}

fluxes and vertical profiles of biogenic volatile organic compounds (BVOCs) suggests that the inflow of anthropogenic precursors/aerosols likely enhanced the formation of both isoprene SOA and $\alpha$-pinene SOA within the forest canopy even when the BVOC flux was relatively low. This study highlights the importance of intra-canopy processes that promote biogenic SOA formation in the presence of significant inflow of oxidants together with anthropogenic aerosols and their precursors.

\section{Introduction}

Forest vegetation contributes substantially to emissions of a variety of biogenic volatile organic compounds (BVOCs), such as isoprene, monoterpenes, and sesquiterpenes, which are involved in plant growth, reproduction, and defense. BVOCs have significant effects on not only insects and other organisms but also atmospheric chemistry and physics. On a global scale, approximately $90 \%$ of annual VOC emissions are derived from biogenic sources, with an estimated amount of about $1000 \mathrm{Tg}$ year $^{-1}$ (Guenther et al., 2012). This is significantly greater (ca. 10 times) than the emission of anthropogenic VOCs. Emission sources of BVOCs in the forest ecosystem include leaves, leaf litter, stems, and roots (Lin et al., 2007; Leff et al., 2008; Aaltonen, et al., 2011; Noe et al., 2012). The emission strength and composition of BVOCs in the forest environment depend on vegetation types, seasons, and meteorological parameters such as temperature, solar 
radiation, and precipitation (Kesselmeier and Staudt, 1999; Guenther et al., 1993; Tani et al., 2002; Kuhn et al., 2004; Mochizuki et al., 2014). Moreover, physical and biological structures of the forest canopy may contribute to chemical loss and deposition of BVOCs within the canopy (Fuentes et al., 2007).

BVOCs are important precursors of organic aerosols (OAs) in the forest atmosphere. The formation of biogenic secondary OA (BSOA) and its transformation by atmospheric processes influence the physicochemical properties of atmospheric aerosols, such as particle hygroscopicity and cloud condensation nuclei (CCN) activity. Because the formation processes of BSOA and its amount are largely uncertain, prediction is difficult. Accurate modeling of BSOA formation requires reliable information about BVOC emissions and a robust understanding of the chemical processing of these precursors inside the forest canopy before entering the atmosphere above the canopy.

The characterization of OAs at the molecular level in forests remains challenging because of multiple contributing sources, variable oxidant concentrations and compositions, and the variable contributions of background gases and aerosols from regions outside forests (e.g., de Gouw and Jimenez, 2009). As discussed by Hallquist et al. (2009), previous studies indicate that the production of BSOA is substantially greater than that of anthropogenic SOA (Kanakidou et al., 2005). Recent studies based on field and laboratory experiments suggest that VOC emissions from biogenic and anthropogenic sources may interact and enhance SOA formation (Goldstein et al., 2009; Emanuelsson et al., 2013; $\mathrm{Xu}$ et al., 2015). To evaluate the contribution of VOCs emitted by forest vegetation to SOA formation, accurate information about emissions and concentrations of VOCs along with concentrations of BSOAs is required. Understanding the formation processes of BSOAs and their controlling factors in forests needs extensive field studies, in which significant amounts of biogenic OA are required to determine clearly the diurnal variations of the biogenic signals. However, studies remain limited in terms of time-resolved, simultaneous measurements of BVOCs and their fluxes and OA at molecular levels in the forest atmosphere.

We conducted ambient measurements of concentrations and canopy-scale fluxes of isoprene and $\alpha$-pinene along with their oxidation products in aerosols in a Larix kaempferi forest in the summer of 2012. Congeneric species of Larix kaempferi such as Larix sibirica and Larix gmelinii grow naturally and widely in boreal coniferous forests in Siberia and northern Europe. Therefore, the vegetation at the current study site might be representative and suitable for characterizing emissions and compositions of BVOCs in boreal forests. The goal of this study is to investigate controlling factors of BSOA formation from BVOC in a forest environment located near anthropogenic sources. Here, we characterize the vertical profiles and temporal variations of BVOCs at this forest site. We also present the analytical results of

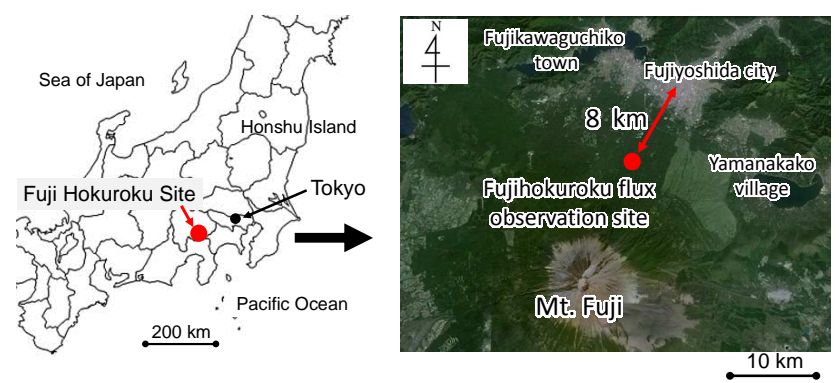

Figure 1. Location of the study site.

molecular tracer compounds for BSOA and explore the controlling factors of the SOA formation in the forest canopy at the measurement site.

\section{Experimental methods}

\subsection{Site description}

Ambient samplings of gas and aerosol were conducted on 5, 10, and 15-17 July 2012 at the Fuji-Hokuroku Flux Research Site $\left(35^{\circ} 26^{\prime} \mathrm{N}, 138^{\circ} 45^{\prime} \mathrm{E}\right)$ (e.g., Mochizuki et al., 2014). The research site is located at the base of Mt. Fuji in Fujiyoshida, Yamanashi, Japan (Fig. 1). The urban area of Fujiyoshida is located about $8 \mathrm{~km}$ northeast of the site. The vegetation type is Larix kaempferi plantation, which was planted uniformly 55 years ago over 150 ha. Tree height was approximately 20 $25 \mathrm{~m}$. The site is surrounded by coniferous and broadleaved mixed forests. A meteorological tower with $32 \mathrm{~m}$ height and a steel scaffold with $20 \mathrm{~m}$ height for tree survey were situated at the center of the forest site. The soil type is coarse-grained volcanic ash. The forest floor is covered mainly with Dryopteris crassirhizoma. Further details of the study site are given by Urakawa et al. (2015). During the entire study period, the ambient temperature at the measurement site ranged between 14.2 and $29.9^{\circ} \mathrm{C}$.

Our previous study reported the annual measurements of biogenic VOC fluxes at the same site, which showed that the fluxes were largest in July and August (Mochizuki et al., 2014). The specific 5 days were selected for the ambient measurements, because some contrast of BVOC emissions and subsequent SOA formation were expected to be observed in terms of photochemical activity and anthropogenic influence. Although the measurements focused on the events over a 5-day period, the data were obtained under typical meteorological conditions at this study site in summer.

\subsection{Measurements of VOCs and flux calculation}

We measured vertical distributions of VOC concentrations at the five altitude levels of 2,10,16, 22 m (just below the forest canopy), and $28 \mathrm{~m}$ (above the canopy) using the meteorological tower. Ambient air was collected into stainless 
steel adsorbent tubes $(88.9 \mathrm{~mm}$ long, $6.35 \mathrm{~mm}$ outer diameter) filled with $200 \mathrm{mg}$ of Tenax-TA (GL Science, Japan) and $100 \mathrm{mg}$ of Carbotrap (Supelco, USA). The air was sampled at a flow rate of $100 \mathrm{~mL} \mathrm{~min}^{-1}$ for $\sim 3 \mathrm{~h}$ using a portable pump (MP- $\sum 30$, Shibata Inc., Japan). The sampling was conducted every $3 \mathrm{~h}$ during daytime (06:00-09:00, 09:0012:00, 12:00-15:00, and 15:00-18:00 LT). To prevent the degradation of VOCs by $\mathrm{O}_{3}$, scrubbers coated with manganese dioxide $\left(\mathrm{MnO}_{2}\right)$ were applied upstream of the adsorbent tubes (Calogirou et al., 1996). Prior to the sampling, the adsorbent tubes were conditioned with purified helium $\left(50 \mathrm{~mL} \mathrm{~min}^{-1}\right)$ at $300^{\circ} \mathrm{C}$ for $10 \mathrm{~min}$ and were stored at approximately $5{ }^{\circ} \mathrm{C}$.

Above-canopy fluxes of VOCs were calculated using a relaxed eddy accumulation (REA) method (Businger and Oncley, 1990):

$F=b \sigma_{w}\left(C^{+}-C^{-}\right)$,

where $\sigma_{w}$ is the standard deviation of vertical wind velocity (w). $C^{+}$and $C^{-}$are the VOC concentrations in the upward and downward air, respectively, collected when the absolute value of the measured vertical wind speed is higher than a dynamic deadband value (Mochizuki et al., 2014). $b$ is an empirical coefficient that can be obtained from sensible heat flux using an eddy covariance method (Hamotani et al., 2001):

$b=\frac{\overline{w^{\prime} T^{\prime}}}{\sigma_{w}\left(\overline{T^{+}}-\overline{T^{-}}\right)}$,

where the overbar denotes an average value over sampling time and the prime represents deviations from a mean value. $T^{+}$and $T^{-}$are air temperature for air with upward and downward directions, respectively. The averaged value of the coefficient $b$ during the whole measurement period was determined to be $0.38\left(r^{2}=0.98\right)$, which was calculated as the slope of $w^{\prime} T^{\prime}$ against $\sigma_{w}\left(T^{+}-T^{-}\right)$.

The REA sampling was conducted at a height of $35 \mathrm{~m}$ using the portable REA sampling system (Mochizuki et al., 2014, and references therein). Three-dimensional wind speed and temperature were measured using a three-dimensional ultrasonic anemometer-thermometer (DA-600-3TV, Sonic, Japan). The measurement frequency of $w$ and $T$ was $10 \mathrm{~Hz}$. The REA sampling was conducted for $55 \mathrm{~min}$ at an interval of $1 \mathrm{~h}$ from 06:00 to 18:00.

Individual VOCs were identified and quantified using a gas chromatograph (GC) coupled to a mass spectrometer (MS) (QP5050A, Shimadzu, Japan) with an SPB-5 capillary column $(60 \mathrm{~m} \times 25 \mathrm{~mm}, 1 \mu \mathrm{m}$ film thickness, Supelco, USA) equipped with a thermal desorption system (Turbo Matrix ATD, Perkin Elmer Instruments, USA) (Mochizuki et al., 2014). Here, we quantified BVOCs including isoprene, monoterpenes, methacrolein (MACR), and methyl vinyl ketone (MVK), as well as anthropogenic VOCs such as benzene, toluene, and methyl ethyl ketone (MEK).

\subsection{Aerosol sampling and analysis}

Total suspended particulate matter (TSP) samplings were conducted at a height of $16 \mathrm{~m}$, just beneath the larch canopy, using a high-volume air sampler (AS-810B, Kimoto Electric, Japan) mounted on the $20 \mathrm{~m}$ steel scaffold. Our previous study showed that BSOA mass resided in the coarse mode observed at the forest site (e.g., pinonic acid $\sim 56 \%$ and 2-methyltetrols (2-MTLs) 33\%) (Miyazaki et al., 2014). In order to collect the total mass of the BSOA tracers, we sampled the TSP in the current study. The ambient particles were collected onto quartz-fiber filters ( 8 inch $\times 10$ inch) (Tissuquartz 2500QAT-UP, Pallflex, USA) at a flow rate of $1200 \mathrm{~L} \mathrm{~min}^{-1}$. The filters were precombusted at $450^{\circ} \mathrm{C}$ for $6 \mathrm{~h}$ prior to the sampling in order to remove organic contaminants. The sampling was conducted every $3 \mathrm{~h}$ during daytime (06:00-09:00, 09:00-12:00, 12:00-15:00, and 15:0018:00 LT) and $12 \mathrm{~h}$ during nighttime (18:00-06:00 LT). The aerosol samples were stored at approximately $-20^{\circ} \mathrm{C}$ until analysis. It is noted that the quartz-fiber filters may adsorb gas-phase compounds, which may cause an overestimate of the mass of the target compound (positive artifacts). On the other hand, it is possible that semi-volatile compounds collected on the filter may evaporate, which may underestimate the mass of the target compound (negative artifacts). However, it is difficult to quantify these effects for ambient conditions in the current study.

For the chemical analysis of biogenic molecular marker compounds, a filter portion $\left(24 \mathrm{~cm}^{2}\right)$ was extracted with dichloromethane/methanol. The $-\mathrm{COOH}$ and $-\mathrm{OH}$ functional groups in the extracts were reacted with N,O-bis(trimethylsilyl) trifluoroacetamide with $1 \%$ trimethylsilyl chloride and $10 \mu \mathrm{L}$ of pyridine at $70^{\circ} \mathrm{C}$ for $3 \mathrm{~h}$ to form trimethylsilyl (TMS) esters and TMS ethers, respectively. The TMS derivatives were analyzed using a capillary GC (HPGC6890, Hewlett-Packard, USA) coupled to a MS (5973 MSD, Agilent, USA) (Fu et al., 2009; Miyazaki et al., 2012). We determined the concentrations of oxidation products of isoprene-2-methylglyceric acid (2-MGA) and 2-MTLs (the sum of 2-methylerythritol and 2-methylthreitol), as well as those of $\alpha$-pinene-pinic acid, pinonic acid, 3-methyl-1,2,3butanetricarboxylic acid (3-MBTCA), and 3-hydroxyglutaric acid (3-HGA). Individual compounds were identified by comparison of mass spectra with those of authentic standards or literature data. For the quantification of pinonic and pinic acids, their GC-MS response factors were determined using authentic standards. The standards were purchased from Sigma Aldrich and Wako Pure Chemical. 2Methylglyceric acid and 2-methyltetrols were quantified using the response factor of meso-erythritol, whereas 3-methyl1,2,3-butanetricarboxylic and 3-hydroxyglutaric acids were estimated using the response factors of pimelic and malic acids, respectively. It is noted that the quantification of these compounds includes some uncertainty due to the use of surrogate standards. Additionally, field blank filters were 

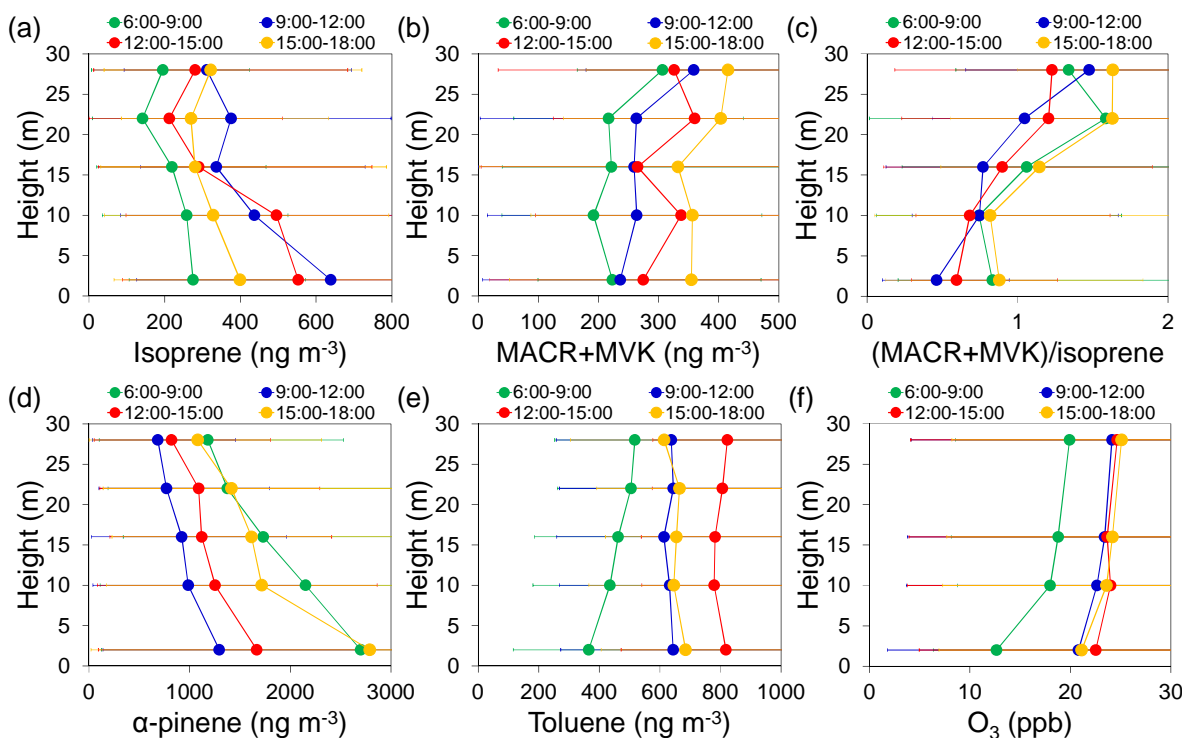

Figure 2. The average vertical profiles of (a) isoprene, (b) MACR + MVK, (c) (MACR + MVK)/isoprene, (d) $\alpha$-pinene, (e) toluene, and (f) $\mathrm{O}_{3}$ during the study period. Data shown are median values with interquartile range.

analyzed for quality assurance. The target organic compounds discussed in this paper were not detected in the blanks.

Another portion $\left(7.07 \mathrm{~cm}^{2}\right)$ of a filter was extracted with ultrapure water under ultrasonication for $15 \mathrm{~min}$ in order to measure inorganic ions. The extracts were filtered through a membrane disk filter $(0.22 \mu \mathrm{m}$, Millipore Millex-GV, Merck, USA) and then introduced to the ion chromatograph (model 761 compact IC, Metrohm, Switzerland) (Miyazaki et al., 2009). Sulfate $\left(\mathrm{SO}_{4}^{2-}\right)$ and nitrate $\left(\mathrm{NO}_{3}^{-}\right)$ions were measured using an SI-90 4E column (Shodex, Showa Denko, Japan) and a $1.8 \mathrm{mM} \mathrm{Na}_{2} \mathrm{CO}_{3}+1.7 \mathrm{mM} \mathrm{NaHCO}$ eluent.

The quartz fiber filters were also used to determine $\mathrm{pH}$ in the water-extracted aerosol samples. A portion of the filter was extracted with $30 \mathrm{~mL}$ ultrapure water. The $\mathrm{pH}$ of the water extracts was measured with a Horiba D-21 pH meter using an electrode (Miyazaki et al., 2014).

\section{$2.4 \mathrm{O}_{3}$ and $\mathrm{NO}_{x}$ measurement}

The concentrations of ozone $\left(\mathrm{O}_{3}\right)$ and nitrogen oxides $\left(\mathrm{NO}_{x}=\mathrm{NO}+\mathrm{NO}_{2}\right)$ were measured every 1 min with an ultraviolet light absorption analyzer (49C, Thermo Scientific, USA) and a chemiluminescence analyzer (42i-TL, Thermo Scientific, USA), respectively, at a flow rate of $3.5 \mathrm{~L} \mathrm{~min}^{-1}$. The ambient air was drawn sequentially from inlets placed at 2, 10, 16 (under the forest canopy), and $28 \mathrm{~m}$ (above the forest canopy) altitude levels on the meteorological tower by automatically switching two-way Teflon solenoid valves every $4 \mathrm{~min}$. The $\mathrm{O}_{3}$ and $\mathrm{NO}_{x}$ instruments were placed inside a shelter on the ground. To prevent degradation of $\mathrm{O}_{3}$ and $\mathrm{NO}_{x}$ by sunlight during the sampling of ambient air, the sampling lines of 1/4 inch PTFE tubing were covered with shade sheet.
On the basis of the response time for $\mathrm{O}_{3}$ and $\mathrm{NO}_{x}$ analyzers in combination with the sampling lines, we discarded $150 \mathrm{~s}$ data for these gases just after switching the solenoid valves.

\subsection{Positive matrix factorization (PMF) for source apportionment}

To investigate factors controlling the formation of biogenic SOA at the study site, we conducted a positive matrix factorization (PMF) (Paatero and Tapper, 1994). The PMF analysis was performed using the concentration values for the measured 17 gas/aerosol species including VOCs and organic tracer compounds as well as inorganic species in aerosols. The sum of the analytical uncertainty and one-third of the detection limit values were used as the overall uncertainty to each input parameter. To find the number of sources, we have tested different numbers of sources (three to five) and found the optimal one with the most physically reasonable results. In this study, the number of sources was determined to be three, to discuss factors controlling the formation of 2-MTLs and 3-MBTCA. These factors are discussed in Sect. 3.4.

\section{Results and discussion}

\subsection{Vertical profiles and diurnal variations of VOC concentrations and fluxes}

\subsubsection{Isoprene and oxygenated VOCs}

On average, isoprene accounted for $23 \%$ of the total terpenoids measured in the present study. The vertical profile of isoprene (Fig. 2a) showed that the concentrations were largest near the forest floor $(\sim 2 \mathrm{~m})$ at all sampling times. 


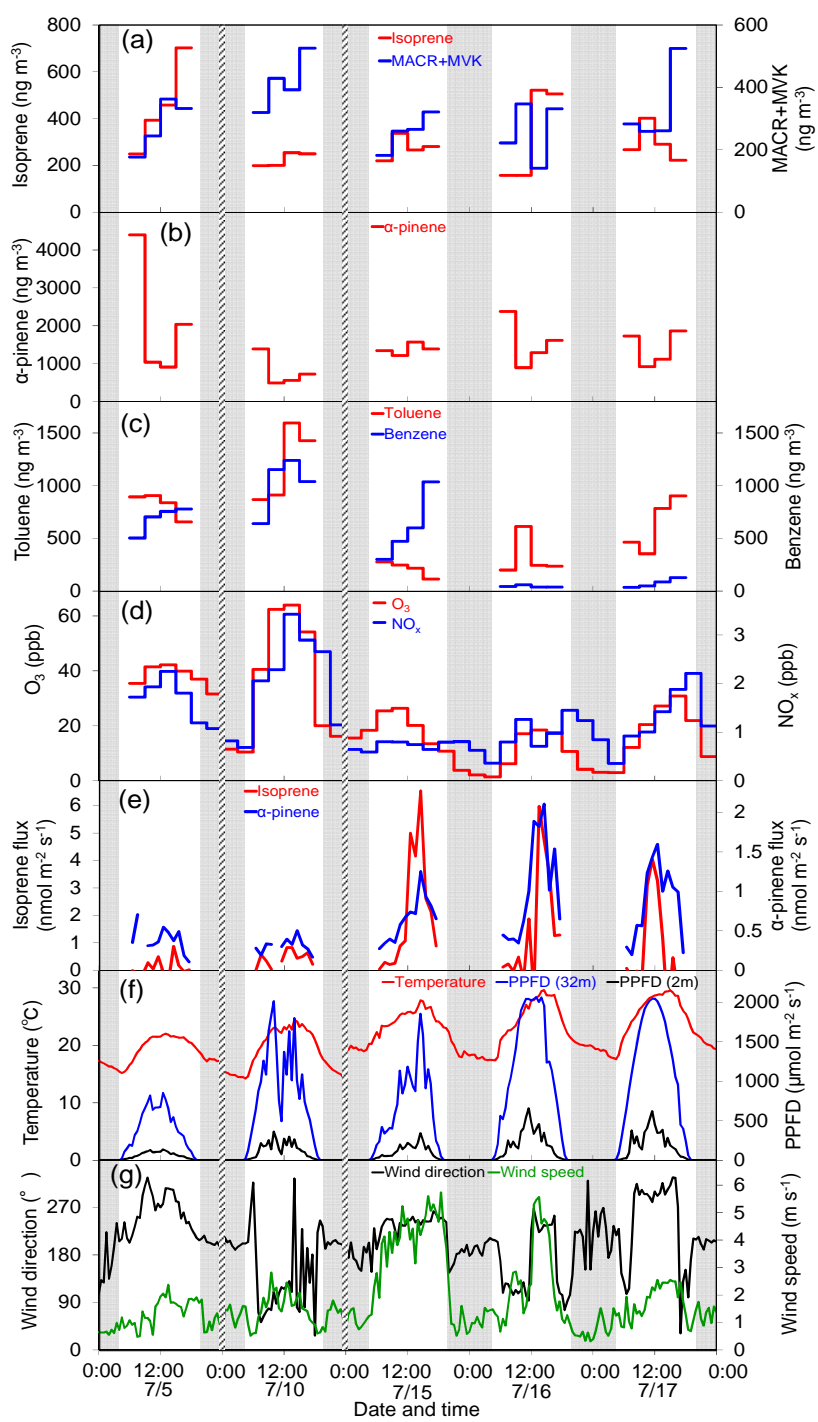

Figure 3. Diurnal variation of (a) isoprene and MACR+MVK, (b) $\alpha$-pinene, (c) toluene and benzene, (d) $\mathrm{O}_{3}$ and $\mathrm{NO}_{x}$, (e) isoprene and $\alpha$-pinene fluxes, (f) temperature and solar radiation, and (g) wind speed and wind direction. Shaded areas indicate nighttime.

At the $16 \mathrm{~m}$ level, where the aerosol sampling was made, the concentrations of isoprene in daytime ranged between 157 and $703 \mathrm{ng} \mathrm{m}^{-3}$ with an average of $316 \mathrm{ng} \mathrm{m}^{-3}$ (Fig. 3a). This value is similar to those observed at a boreal forest site in Hyytiälä, Finland ( $300 \mathrm{ng} \mathrm{m}^{-3}$ ) (Hakola et al., 2003).

The diurnal profile of isoprene (Fig. 2a) showed the maximum concentration around noon at all altitude levels. This diurnal pattern is in agreement with the dependency of isoprene emission on ambient light and temperature (e.g., Guenther et al., 1993). In our previous study, fern species D. crassirhizoma growing on the forest floor was found to be a dominant emitter of isoprene at this forest site (Mochizuki et al., 2014). The leaf area index (LAI) in summer at this study site is about 2.8 (Okano and Arase, 2007), which is considerably lower than the typical value in forests with similar vegetation types (e.g., $\sim 5-6$ in a Pinus ponderosa L. forest site, USA). This means that the forest canopy at the study site is not fully covered with leaves, allowing large amounts of solar radiation to reach the forest floor level in daytime. Sunlight transmittance through the forest canopy likely leads to the enhancement of isoprene emission from $D$. crassirhizoma on the forest floor.

Figure $2 b$ shows vertical profiles of the sum of two isoprene oxidation products, methacrolein (MACR) and methyl vinyl ketone (MVK). The concentrations of MACR + MVK were generally higher above $25 \mathrm{~m}$, although they did not exhibit clear vertical gradients within the forest canopy. These profiles result in substantially higher ratios of $(\mathrm{MACR}+\mathrm{MVK}) /$ isoprene (1.2-1.6) near the forest canopy $(22 \mathrm{~m})$ compared to those at the $2 \mathrm{~m}$ height near the forest floor (0.5-0.9) (Fig. 2c). The MACR + MVK concentrations reached a maximum in the afternoon. The delay of a few hours in the increase of MACR + MVK concentrations likely represents the timescale required for isoprene degradation. Indeed, this timescale is similar to that reported for the known reaction of isoprene with a typical $\mathrm{OH}$ radical concentration of $2.0 \times 10^{6}$ molecules $\mathrm{cm}^{-3}(\sim 2 \mathrm{~h}$ ) (Atkinson and Arey, 2003). These results indicate dominant emission of isoprene from the forest floor vegetation, followed by degradation to form the first-order oxidation products MACR and MVK at the study site. It is noted that uptake of MACR and MVK by tree leaves has been suggested as an important sink of oxygenated VOCs in the forest environment (Tani et al., 2010; Karl et al., 2010). However, the significance of the uptake of these VOCs by leaves is not clear from our data.

Diurnal variations in the above-canopy flux of isoprene showed that the flux of isoprene had distinct peaks around noon from 15 to 17 July when the ambient temperature exceeded $25^{\circ} \mathrm{C}$ (Fig. 3e and f). The emission of isoprene is often presented as a function of temperature and light intensity (Guenther et al., 1993). The observed isoprene fluxes did indeed depend on both ambient temperature and photosynthetic photon flux density (PPFD) near the forest floor (Fig. 4a and b). To further analyze the meteorological responses of isoprene emissions, we calculated the temperature and light dependence of isoprene emissions, $I_{\mathrm{S}}$, under standard conditions of temperature $\left(30^{\circ} \mathrm{C}\right)$ and PPFD $\left(1000 \mu \mathrm{mol} \mathrm{m}^{-2} \mathrm{~s}^{-1}\right)$ using an algorithm proposed by Guenther et al. (1993). Figure 4c shows the observed isoprene flux plotted against functions describing the dependence of the PPFD $\left(C_{L}\right)$ and ambient temperature $\left(C_{T}\right)\left(r^{2}=0.53\right) . I_{\mathrm{S}}$ was calculated to be $6.0 \mathrm{nmol} \mathrm{m}^{-2} \mathrm{~s}^{-1}$, which was lower than that reported for a mixture of coniferous and deciduous forest in Europe (8.2-13.0 nmol m $\mathrm{n} \mathrm{s}^{-1}$ ) (Laffineur et al., 2011). This suggests that the isoprene fluxes at this forest site were characterized by lower sensitivity to temperature and light compared to other forest sites with similar vegetation types. 
(a)

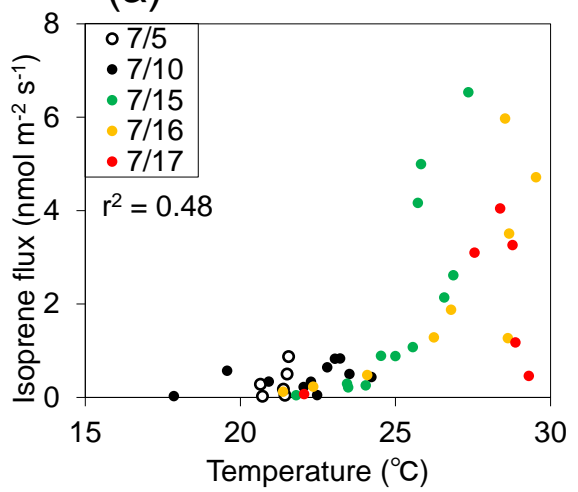

(c)

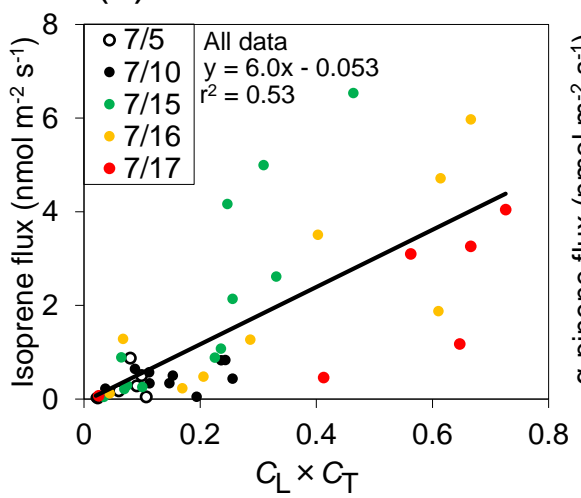

(b)

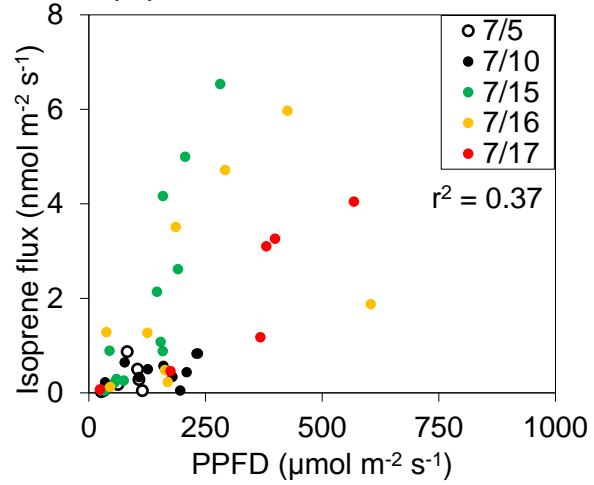

(d)

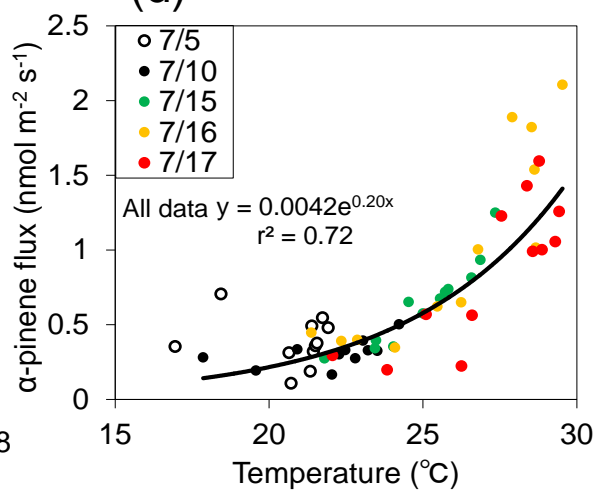

Figure 4. Isoprene fluxes against the (a) ambient temperature, (b) photosynthetic photon flux density (PPFD), and (c) temperature and light activity factor $\left(C_{L} \times C_{T}\right)$ and (d) $\alpha$-pinene flux against the ambient temperature.

\subsection{2 $\alpha$-pinene}

Our previous work reported that monoterpenes are emitted mainly by $L$. kaempferi at this forest site (Mochizuki et al., 2014). On average, $\alpha$-pinene accounted for $44 \%$ of the total terpenoid measured in the present study. Figures $2 \mathrm{~d}$ and $3 \mathrm{~b}$ depict the vertical and diurnal variations in the $\alpha$-pinene concentrations, respectively. The highest concentrations of $\alpha$-pinene were observed near the forest floor $(2 \mathrm{~m})$, and the concentrations decreased with increasing height at any time of the day (Fig. 2d). Similar vertical profiles of $\alpha$-pinene have been reported for hemiboreal mixed forest sites by some previous studies (Holzinger et al., 2005; Noe et al., 2012). The clear vertical gradient indicates emission sources of $\alpha$-pinene near the forest floor. In fact, emission of monoterpene from the soil surface including fallen needles/branches and roots has been suggested as an important source of $\alpha$-pinene (e.g., Hayward et al., 2001; Lin et al., 2007; Aaltonen et al., 2011) and its oxidation products in aerosols (Faiola et al., 2014). The vertical gradient of $\alpha$-pinene found in the present study suggests that $\alpha$-pinene is emitted not only from L. kaempferi leaves but also from the forest floor, such as from litter and/or roots.
The daytime concentrations of $\alpha$-pinene ranged between 489 and $4395 \mathrm{ng} \mathrm{m}^{-3}$, with an average of $1444 \mathrm{ng} \mathrm{m}^{-3}$. The observed range of the $\alpha$-pinene concentrations was similar to those reported for Californian pine forest $\left(60-1800 \mathrm{ng} \mathrm{m}^{-3}\right)$ (Goldstein et al., 2004) and for Hyytiälä, Finland (60$350 \mathrm{ng} \mathrm{m}^{-3}$ ) (Spanke et al., 2001). The diurnal variations of $\alpha$-pinene showed that the concentrations generally increased in the morning (06:00-09:00 LT) at the $16 \mathrm{~m}$ level (Fig. 3b). Indeed, increased concentrations of monoterpene in the morning have been observed at other forest sites (e.g., Holzinger et al., 2005). The emission of $\alpha$-pinene from L. kaempferi, which depends solely on temperature (e.g., Guenther et al., 1993), may continue during night. This continued emission results in accumulation of $\alpha$-pinene in the forest canopy. Moreover, the low wind speeds during the night $\left(<2 \mathrm{~m} \mathrm{~s}^{-1}\right)$ (Fig. 3g) indicate relatively stable atmospheric conditions with less vertical mixing within the forest canopy. This may cause stagnation of $\alpha$-pinene followed by increased concentrations near the forest floor in the morning.

Similarly to isoprene, the above-canopy flux of $\alpha$-pinene exhibited distinct peaks around noon on 15, 16, and 17 July (Fig. 3e). It is recognized that the emission of $\alpha$-pinene depends on temperature alone (e.g., Guenther et al., 1993). In fact, the above-canopy flux of $\alpha$-pinene was 
found to increase exponentially with temperature $\left(r^{2}=0.72\right)$ (Fig. 4d). We determined the basal flux at the standard temperature $T_{\mathrm{S}}\left(30^{\circ} \mathrm{C}\right), F_{\mathrm{s}}$, which was $0.88 \mathrm{nmol} \mathrm{m}^{-2} \mathrm{~s}^{-1}$ using the temperature-flux algorithm (Guenther et al., 1993). This value is close to the previous data in 2011 (Mochizuki et al., 2014 ) and the $F_{\mathrm{S}}$ value reported for a Pinus sylvestris forest in Europe $\left(1.3 \mathrm{nmol} \mathrm{m}^{-2} \mathrm{~s}^{-1}\right)$ (Rinne et al., 2000).

\subsubsection{Influence of anthropogenic sources}

Here, we examine the influence of anthropogenic air transported from outside the forest site. The concentrations of toluene, which is used as a tracer for anthropogenic sources, showed little vertical gradient except for the early morning (06:00-09:00 LT) (Fig. 2e). The vertical gradients of $\mathrm{O}_{3}$ concentrations were relatively low during the daytime, indicating intense vertical mixing.

The $\mathrm{O}_{3}$ concentrations showed clear diurnal profiles during the study period (Fig. 3d). In particular, the concentration increased during the early morning and reached a daily maximum of more than $60 \mathrm{ppbv}$ in the early afternoon on $10 \mathrm{July}$. The dominant wind on that day during daytime was northeasterly and easterly (Fig. 3g), indicating inflow of air masses from the urban area (Fig. 1). On the other hand, the dominant wind direction on the other days was southerly and southwesterly, indicating transport of air from the forested and/or mountain areas. This was supported by lower concentrations of toluene, benzene, and $\mathrm{NO}_{x}$ on 5 July and 15-17 July.

\subsection{Oxidation products of isoprene in the aerosol phase}

Figure 5a presents temporal variations in the concentrations of molecular markers for isoprene oxidation products, 2-methylglyceric acid (2-MGA) and 2-methyltetrols (2-MTLs), at the $16 \mathrm{~m}$ level. The average concentrations of 2-MGA and 2-MTLs were $4.5 \pm 3.6 \mathrm{ng} \mathrm{m}^{-3}$ and $14.0 \pm$ $6.8 \mathrm{ng} \mathrm{m}^{-3}$, respectively (Table 1 ). The average concentration of 2-MTLs was similar to that reported for a deciduous broadleaf forest in northern Japan in summer $\left(\sim 20 \mathrm{ng} \mathrm{m}^{-3}\right)$ (Miyazaki et al., 2014).

The concentrations of 2-MGA and 2-MTLs exhibited clear diurnal variations with a maximum in the afternoon. These temporal variations generally followed that of isoprene, suggesting local production of isoprene-derived OA within the forest canopy. Laboratory experiments showed that the timescale for 2-MGA and 2-MTLs production from isoprene oxidation is a few hours (e.g., Surratt et al., 2010). This timescale is comparable to the sampling duration $(\sim$ $3 \mathrm{~h}$ ) during the daytime in this study, which is consistent with the similar temporal trend of the concentrations of isoprene, 2-MGA and 2-MTLs. It is noted that the concentrations of 2MGA and 2-MTLs showed higher values (up to $\sim 10$ and $\sim 30 \mathrm{ng} \mathrm{m}^{-3}$, respectively) on 10 and 17 July. On these 2 days, the (MACR + MVK)/isoprene and 2-MTLs/isoprene ratios were 2- to 6-fold higher than those on the other days

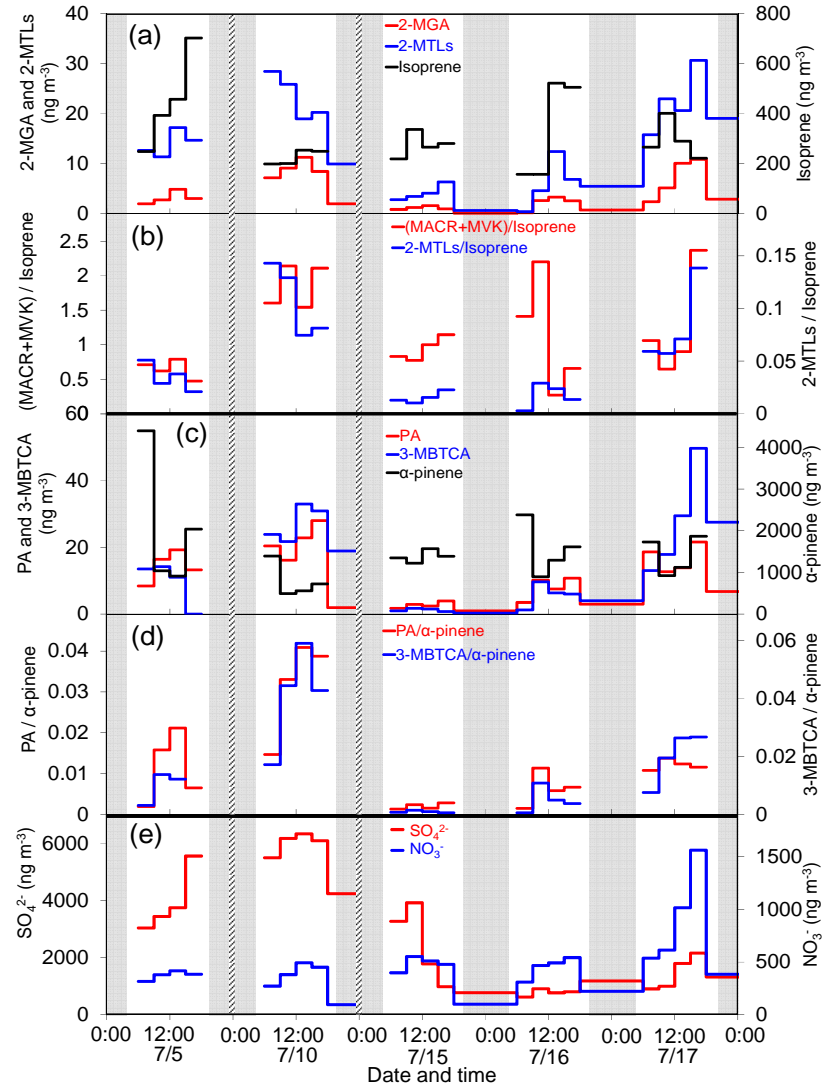

Figure 5. Diurnal variations of (a) 2-MGA, 2-MTLs, and isoprene, (b) the ratios of (MACR + MVK)/isoprene and 2-MTLs/isoprene, (c) PA, 3-MBTCA, and $\alpha$-pinene, (d) the ratios of PA/ $\alpha$-pinene and 3-MBTCA/ $\alpha$-pinene, and (e) $\mathrm{SO}_{4}^{2-}$ and $\mathrm{NO}_{3}^{-}$at the $16 \mathrm{~m}$ altitude level on 5, 10, and 15-17 July. Shaded areas indicate nighttime.

(Fig. 5b). On the other hand, the concentrations and abovecanopy flux of isoprene were similar to or even lower than those on the other days (Fig. 3a and e). These results suggest that the reactivity of isoprene to form OAs was considerably higher on those specific days. This is supported by elevated concentrations of $\mathrm{SO}_{4}^{2-}$ and $\mathrm{O}_{3}$ as shown in Figs. 5e and $3 \mathrm{~d}$, respectively. In particular, the 2-MGA/isoprene and 2-MTLs/isoprene ratios increased with increasing levels of $\mathrm{O}_{3}$ (Fig. 6a and b). In fact, anthropogenic influence on the observed aerosols was significant on 10 July, as evident from the substantially large concentrations of $\mathrm{SO}_{4}^{2-}$ $\left(\sim 6400 \mathrm{ng} \mathrm{m}^{-3}\right), \mathrm{O}_{3}(\sim 65 \mathrm{ppbv})$, and $\mathrm{NO}_{x}(\sim 3.5 \mathrm{ppbv})$ on that day. The processes for the isoprene oxidation producing OAs will be discussed in detail in Sect. 3.4.

\subsection{Oxidation products of $\alpha$-pinene in the aerosol phase}

Figure $5 \mathrm{c}$ presents temporal variations in the concentrations of pinonic acid (PA) and 3-MBTCA at the $16 \mathrm{~m}$ altitude level. PA and 3-MBTCA showed enhanced concentrations in daytime (Fig. 5c), whereas the concentration of $\alpha$-pinene was 
Table 1. Concentrations of biogenic VOC, biogenic SOA, inorganic ions, and oxidants detected in the Larix kaempferi forest.

\begin{tabular}{|c|c|c|c|c|c|c|c|c|}
\hline \multirow[t]{2}{*}{ Compounds } & \multicolumn{4}{|c|}{$\begin{array}{c}\text { Daytime } \\
\text { concentration }\end{array}$} & \multicolumn{4}{|c|}{$\begin{array}{c}\text { Nighttime } \\
\text { concentration }\end{array}$} \\
\hline & Mean & SD & Min & $\operatorname{Max}$ & Mean & SD & Min & $\operatorname{Max}$ \\
\hline \multicolumn{9}{|l|}{ Biogenic VOCs $\left(\mathrm{ng} \mathrm{m}^{-3}\right)$} \\
\hline Isoprene & 316 & 139 & 157 & 703 & NA & NA & NA & NA \\
\hline$\alpha$-pinene & 1444 & 837 & 489 & 4395 & NA & NA & NA & NA \\
\hline \multicolumn{9}{|c|}{ Anthropogenic VOCs $\left(\mathrm{ng} \mathrm{m}^{-3}\right)$} \\
\hline MEK & 130 & 105 & 15 & 329 & NA & NA & NA & NA \\
\hline Benzene & 485 & 415 & 34 & 1241 & NA & NA & NA & NA \\
\hline Toluene & 637 & 411 & 144 & 1594 & NA & NA & NA & NA \\
\hline \multicolumn{9}{|c|}{ Oxidation products of isoprene $\left(\mathrm{ng} \mathrm{m}^{-3}\right)$} \\
\hline MACR & 146 & 44 & 71 & 252 & NA & NA & NA & NA \\
\hline MVK & 163 & 62 & 70 & 320 & NA & NA & NA & NA \\
\hline \multicolumn{9}{|c|}{ Isoprene SOA tracers $\left(\mathrm{ng} \mathrm{m}^{-3}\right)$} \\
\hline 2-methylglyceric acid & 4.5 & 3.6 & 0.2 & 11.3 & 1.4 & 1.3 & 0.1 & 3 \\
\hline 2-methyltetrols & 14.0 & 6.8 & 0.4 & 30.7 & 8.8 & 6.3 & 0.7 & 19 \\
\hline 2-methylthreitol & 4.2 & 2.9 & 0.2 & 9.5 & 2.2 & 1.9 & 0.2 & 4 \\
\hline 2-methylerythritol & 9.8 & 6.2 & 0.3 & 21.2 & 6.6 & 6.0 & 0.5 & 15 \\
\hline \multicolumn{9}{|c|}{$\alpha$-pinene SOA tracers $\left(\mathrm{ng} \mathrm{m}^{-3}\right)$} \\
\hline Pinonic acid & 12.7 & 7.7 & 1.7 & 28.0 & 3.1 & 2.6 & 0.9 & 6.8 \\
\hline Pinic acid & 4.9 & 5.0 & 0.0 & 18.2 & 6.4 & 5.8 & 0.8 & 14.5 \\
\hline 3-hydroxyglutaric acid & 14.4 & 13.7 & 1.6 & 44.0 & 15.9 & 15.8 & 1.0 & 35.6 \\
\hline 3-МBTCA & 14.3 & 13.6 & 0.0 & 49.7 & 12.7 & 12.8 & 0.3 & 27.5 \\
\hline \multicolumn{9}{|l|}{ Inorganic ions $\left(\mathrm{ng} \mathrm{m}^{-3}\right)$} \\
\hline $\mathrm{SO}_{4}^{2-}$ & 2937 & 2065 & 617 & 6331 & 1875 & 1592 & 767 & 4237 \\
\hline $\mathrm{NO}_{3}^{-}$ & 529 & 289 & 271 & 1562 & 200 & 136 & 95 & 385 \\
\hline $\mathrm{O}_{3}(\mathrm{ppb})$ & 29.4 & 16.2 & 4.6 & 63.0 & 13.5 & 11.0 & 4.0 & 30.8 \\
\hline $\mathrm{NO}_{x}(\mathrm{ppb})$ & 1.5 & 0.8 & 0.6 & 3.3 & 1.0 & 0.3 & 0.6 & 1.3 \\
\hline
\end{tabular}

highest in the morning for most of the observational period, as shown in Fig. 3b. PA is formed by the ozonolysis and photooxidation of $\alpha$ - and $\beta$-pinene via reactions with $\mathrm{O}_{3}$ and $\mathrm{OH}$ radicals (e.g., Yu et al., 1999). The lifetime of $\alpha$-pinene with $\mathrm{OH}$ is estimated to be $\sim 3.4 \mathrm{~h}$ at $25^{\circ} \mathrm{C}$ assuming the $\mathrm{OH}$ concentration of $1.5 \times 10^{6}$ molecules $\mathrm{cm}^{-3}$. Meanwhile, the lifetime of $\alpha$-pinene with $\mathrm{O}_{3}$ is $\sim 4.6 \mathrm{~h}$ based on our $\mathrm{O}_{3}$ measurement data $(\sim 30 \mathrm{ppb})$. The first-generation product of $\alpha$ - and $\beta$-pinene is further oxidized to higher-generation oxidation products through $\mathrm{OH}$ radical-initiated reactions. Further reaction of the initial oxidation products of pinene leads to highly oxidized polar compounds (e.g., 3-MBTCA) (Szmigielski et al., 2007; Kourtchev et al., 2009; Müller et al., 2012). With regard to the production of 3-MBTCA by $\mathrm{OH}$-initiated oxidation of $\alpha$-pinene, the timescale of the 3MBTCA formation $(>\sim 3 \mathrm{~h})$ shown by laboratory experiments (e.g., Eddingsaas et al., 2012; Kristensen et al., 2013) is longer than the sampling time during the daytime in the current study. The difference in the diurnal peaks of the concentrations of $\alpha$-pinene and its oxidation products in aerosols can be explained by the timescale for such atmospheric reactions of $\alpha$-pinene to form SOA.

Similar to the temporal variations of 2-MGA and 2-MTLs, the concentrations of PA and 3-MBTCA on 10 and 17 July were considerably higher than those on the other days. The elevated ratios of $\mathrm{PA} / \alpha$-pinene (up to $\sim 0.04$ ) and 3 MBTCA/ $\alpha$-pinene (up to $\sim 0.06$ ) on 10 July (Fig. $5 \mathrm{~d}$ ) compared to those on the other days suggest that the atmospheric reactivity of $\alpha$-pinene was more pronounced on that day. This is also evident from Fig. $6 \mathrm{c}$ and d, which showed positive correlations of the $\mathrm{PA} / \alpha$-pinene and 3-MBTCA $/ \alpha$-pinene ratios with $\mathrm{O}_{3}\left(r^{2}=0.67\right)$. In contrast to this, the concentrations and above-canopy flux of $\alpha$-pinene on 10 July were markedly lower than those on 17 July. This suggests the importance of reactivity of $\alpha$-pinene to form SOA. Possible controlling factors for the production of $\alpha$-pinene-derived SOA as well as isoprene-derived SOA are discussed in Sect. 3.4. 
(a)

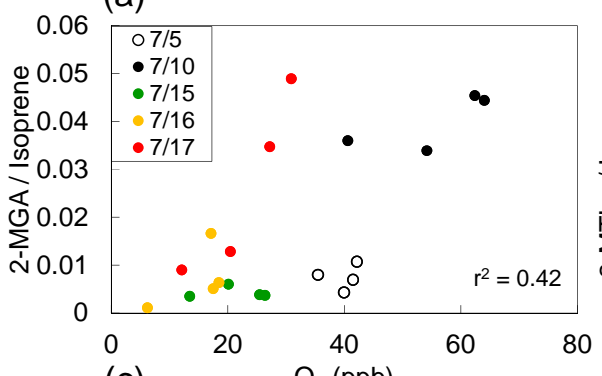

(c) $\quad \mathrm{O}_{3}(\mathrm{ppb})$

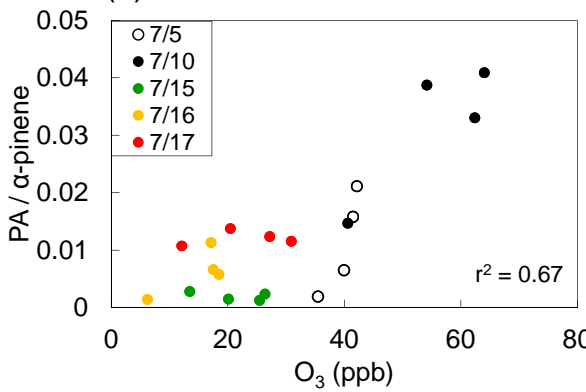

(b)
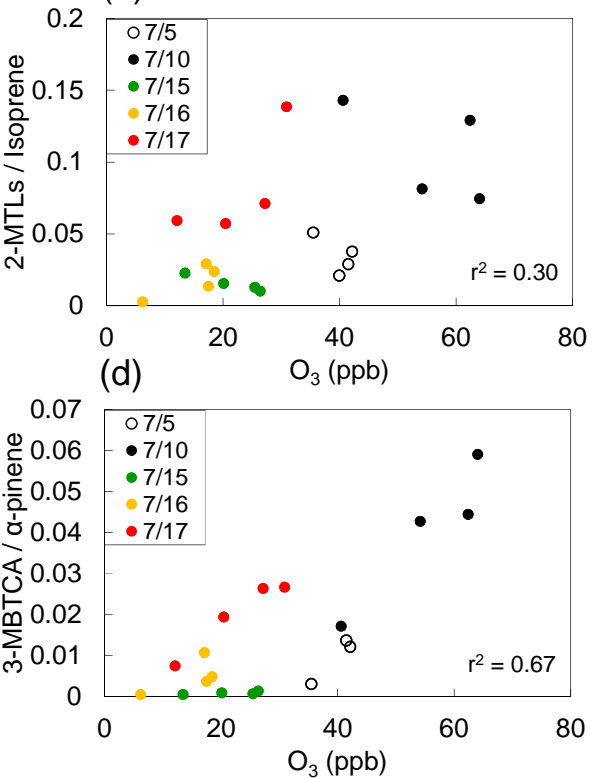

Figure 6. The ratios of (a) 2-MGA/isoprene, (b) 2-MTLs/isoprene, (c) PA/ $\alpha$-pinene, and (d) 3-MBTCA/ $\alpha$-pinene as a function of the $\mathrm{O}_{3}$ mixing ratios.

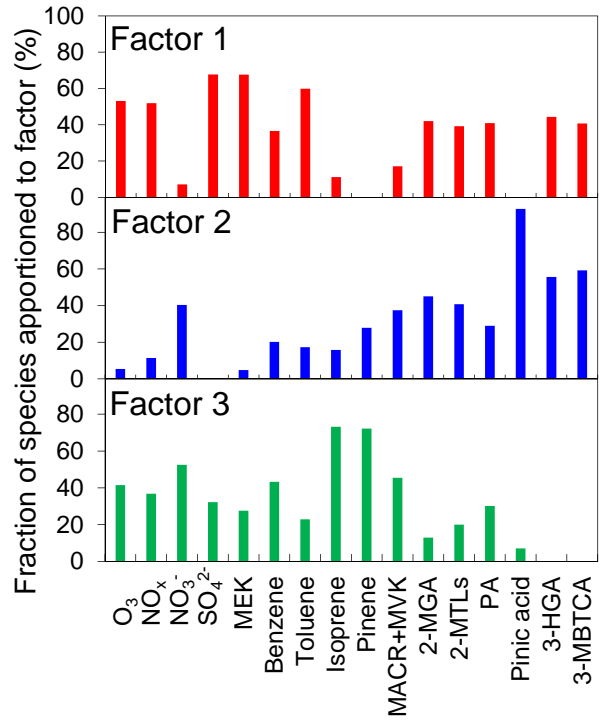

Figure 7. Three compositional factors isolated by PMF.

\subsection{Controlling factors of biogenic SOA formation}

Figure 7 shows composition profiles for the three factors resolved by the PMF. Although the data were obtained under typical meteorological conditions at this study site in summer, the PMF results can be interpreted with caution due to the limited number of the data. Factor 1 (F1) was dominated by large fractions of $\mathrm{O}_{3}(53 \%), \mathrm{NO}_{x}(52 \%), \mathrm{SO}_{4}^{2-}(68 \%)$, and toluene $(60 \%)$, indicating a larger influence of anthro-

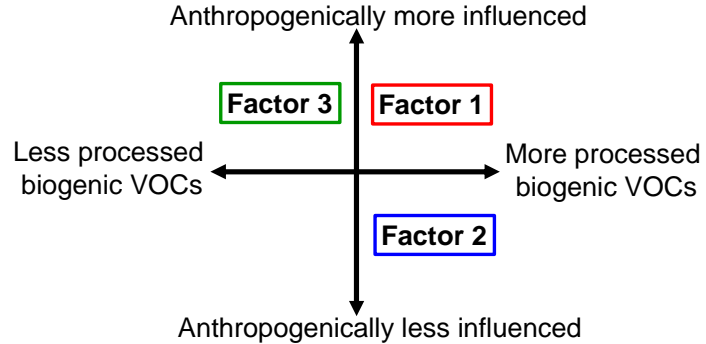

Figure 8. Schematic of each characteristic of the three PMF factors in terms of the degree of anthropogenic influence and processing of biogenic VOCs.

pogenic sources. Factor 2 (F2) was characterized by smaller fractions of these species and was dominated by oxidation products in aerosols, such as 2-MGA, pinic acid, 3-HGA, and 3-MBTCA. Factor 3 (F3) was dominated by isoprene (71\%) and $\alpha$-pinene $(70 \%)$, whereas contributions of anthropogenic tracers $\left(\mathrm{NO}_{x}\right.$ and benzene) are as large as those to F1. Based on the results above, F1, F2, and F3 are referred to here as "anthropogenically more influenced/more processed biogenic VOCs", "anthropogenically less influenced/more processed biogenic VOCs", and "anthropogenically more influenced/less processed biogenic VOCs", respectively (Fig. 8).

Figure 9 shows time series of the estimated relative contributions of the different factors to the concentrations of 2-MTLs and 3-MBTCA resolved by PMF on each day. It is noteworthy that the contributions of each factor to the 


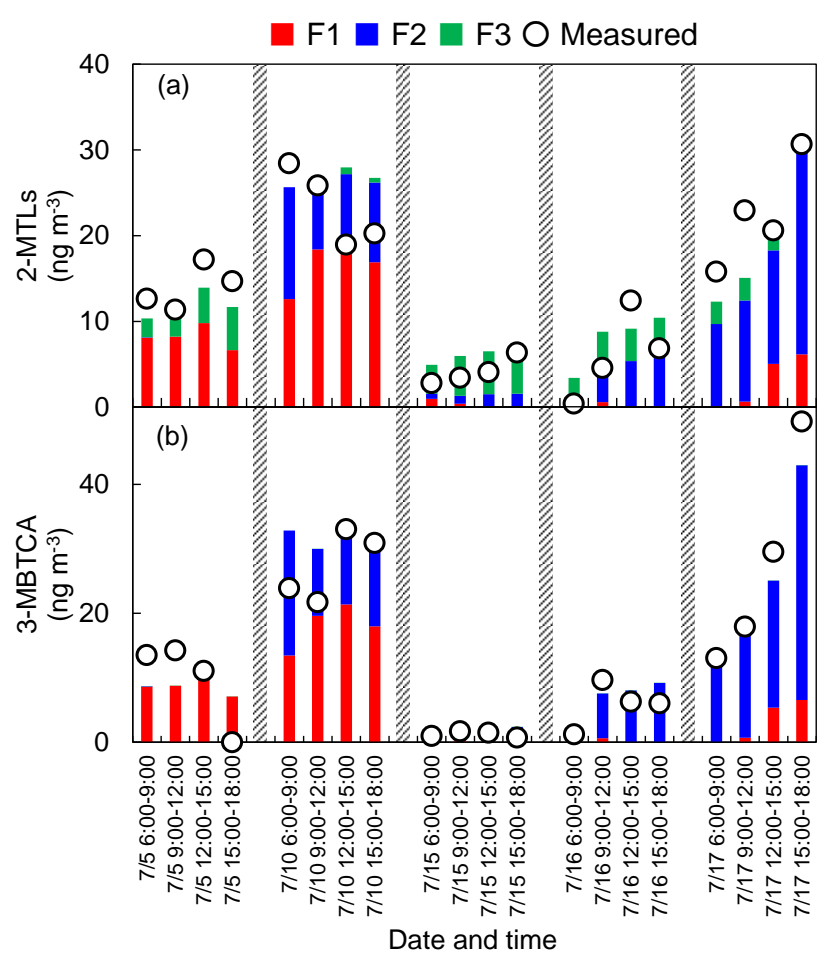

Figure 9. Time series of estimated relative contributions of different factors to the concentrations of (a) 2-MTLs and (b) 3-MBTCA resolved by PMF on each day. Open circles indicate the measured concentrations within the forest canopy.

elevated concentrations of 2-MTLs and 3-MBTCA are different between 10 and 17 July. On 10 July, F1 was a dominant contributor to 2-MTLs (64\%) and 3-MBTCA (57\%). In contrast, contributions of F2 to 2-MTLs $(75 \%)$ and 3MBTCA $(90 \%)$ were predominant on 17 July. As stated in the previous sections, anthropogenic influence on the observed aerosols was significant on 10 July. The PMF result indicates that anthropogenic inflow and subsequent oxidation of both isoprene and $\alpha$-pinene likely enhanced SOA formation within the forest canopy, despite the relatively low above-canopy fluxes of BVOCs.

$\mathrm{OH}$ oxidation of isoprene is initiated by the addition of hydroxyl radicals to the double bonds of isoprene. The alkyl radicals formed in the air react with oxygen $\left(\mathrm{O}_{2}\right)$ to form alkyl peroxyl radicals $\left(\mathrm{HOC}_{5} \mathrm{H}_{8} \mathrm{OO}\right)$, commonly called ISOPOO. ISOPOO radicals subsequently react with either NO (Tuazon and Atkinson, 1990), hydroperoxyl radicals $\mathrm{HO}_{2}$ (Paulot et al., 2009), or organic peroxyl radicals $\mathrm{RO}_{2}$ (Jenkin et al., 1998). Under high $\mathrm{NO}_{x}$ conditions, the dominant fate of ISOPOO is generally a reaction with NO. For SOA formed from isoprene oxidation, the existence of particle-phase acid-catalyzed reactions has been demonstrated, and this leads to the formation of 2-MTLs and highmolecular-weight products of SOA (Surratt et al., 2007). Edney et al. (2005) found that concentrations of 2-MGA and
2-MTLs increased significantly under acidic conditions. Recent studies have suggested that 2-MTLs can be formed via reactions of reactive intermediates, isoprene epoxydiols (IEPOX) (e.g., Surrat et al., 2010; Lin et al., 2014). It has been shown that isoprene SOA is enhanced in the presence of acidified sulfate seed aerosol, where acid-catalyzed particlephase reactions increase the uptake of IEPOX (e.g., Surrat et al., 2010; Lin et al., 2014). Indeed, we also observed $\mathrm{C}_{5}$ alkene triols, which is a particle-phase product from reactive uptake of IEPOX as well. The average concentration of $\mathrm{C}_{5}$-alkene triols was $7.8 \pm 6.7 \mathrm{ng} \mathrm{m}^{-3}$, which is comparable to that of 2-MTLs. The presence of $\mathrm{C}_{5}$-alkene triols with its significant positive correlation with 2-MTLs $\left(r^{2}=0.67\right)$ supports the IEPOX uptake chemistry that leads to 2-MTLs formation suggested by previous studies (e.g., Surratt et al., 2010).

In order to further examine the effect of aerosol acidity on the formation of 2-MTLs, we measured $\mathrm{pH}$ in the waterextracted samples (Sect. 2.3). The $\mathrm{pH}$ in the extracted samples may not represent the true aerosol $\mathrm{pH}$, but is used here as an indicator of the aerosol $\mathrm{pH}$, which offers insights into the aerosol acidity. The resulting $\mathrm{pH}$ of the water-extracted samples ranged from about 4.2 to 6.4 , indicating that the observed aerosols were generally acidic. The 2-MTLs concentrations showed a negative correlation with $\mathrm{pH}\left(r^{2}=0.45\right)$ and a positive correlation with the $\mathrm{SO}_{4}^{2-}$ concentrations $\left(r^{2}=0.31\right)$. This relation between 2-MTLs and indicators of the acidity suggests that the aerosol acidity likely contributed to the formation of 2-MTLs at the forest site.

Moreover, a recent field study indicated that a significant fraction of 2-MTLs exists in the gas phase (Isaacman et al., 2013). It is thus likely that volatilization of methyltetrols from the fine particles occurs and is followed by gasparticle repartitioning. In addition to the photooxidation of isoprene, Nozière et al. (2011) suggested that some fraction of 2-MTLs is likely of primary biological origin, which may be associated with production by plants, algae, and other living organisms. However, the average local wind speeds on 10 and 17 July were much lower $\left(<2 \mathrm{~m} \mathrm{~s}^{-1}\right)$ than those on 15-16 July (Fig. 3f), indicating that any primary biological origin contribution to the observed 2-MTLs was likely minor in this study.

With regard to $\alpha$-pinene SOA, Emanuelsson et al. (2013) conducted photo-oxidation experiments with a mixture of biogenic and anthropogenic precursors. They suggested that even small contributions of anthropogenic SOA can reduce the volatility of $\alpha$-pinene-derived SOA. BSOA from $\alpha$-pinene is formed already at low $\mathrm{OH}$ levels and vapors with high vapor pressures reach saturation, which contribute to the BSOA mass (Pankow, 1994). These vapors can react with $\mathrm{OH}$, which leads to increasing second-generation products with low volatility, such as 3-MBTCA (Müller et al., 2012). Although $\mathrm{OH}$ measurement is not available in the present study, our data on 10 July indicate that mixed 
anthropogenic/biogenic SOA with $\mathrm{OH}$ likely resulted in the enhanced concentrations of 3-MBTCA (Fig. 9b). More recently, Ehn et al. $(2012,2014)$ and Schobesberger et al. (2013) have observed highly oxidized multifunctional organic compounds (i.e., extremely low-volatility organic compounds (ELVOCs)) based on laboratory experiments and ambient measurements at a boreal forest site. ELVOCs can be formed by the ozonolysis of $\alpha$-pinene. Because the ELVOCs are shown to form at significant mass yield, the formation of 3-MBTCA via $\mathrm{OH}$ and $\mathrm{O}_{3}$ reactions with $\alpha$-pinene is likely linked to the formation of ELVOCs. Although we have not discussed the total amount of SOA in this study, the observed increase in the 3-MBTCA and $\mathrm{O}_{3}$ levels on 10 and 17 July indicates that the formation of ELVOC and their contribution to the total SOA mass were expected to be significant. In summary, the present results suggest that the anthropogenic inflow and subsequent oxidation of isoprene and $\alpha$-pinene promoted BSOA formation within the forest canopy despite the lower concentrations and above-canopy fluxes of those VOCs.

\section{Conclusions}

We measured concentrations and canopy-scale fluxes of isoprene and $\alpha$-pinene simultaneously with their oxidation products in total suspended particles (TSP) at a Larix kaempferi forest site in summer. Isoprene and $\alpha$-pinene accounted for 23 and $44 \%$, respectively, of the total terpenoids measured in this study. Vertical and diurnal profiles of isoprene and MACR + MVK suggest large emissions of isoprene near the forest floor, which is likely due to Dryopteris crassirhizoma, followed by reaction of the isoprene within the L. kaempferi canopy. The concentrations of $\alpha$-pinene also showed peaks near the forest floor with maximums in the early morning and late afternoon, suggesting significant emissions of $\alpha$-pinene from soil and litter in addition to emissions from leaves at the forest site.

Isoprene and its oxidation products in aerosols exhibited similar diurnal variations within the forest canopy, providing evidence of SOA formation within a timescale of a few hours via oxidation of isoprene emitted from Dryopteris crassirhizoma on the forest floor. PMF analysis indicated that anthropogenic inflow likely contributed to the enhanced concentrations of both isoprene-derived (> 64\%) and $\alpha$-pinenederived ( $>57 \%$ ) SOA within the forest canopy. The combined analyses of the fluxes and vertical profiles of BVOCs suggest that the BSOA formation promoted by the anthropogenic inflow was enhanced within the forest canopy even though the BVOC fluxes were relatively low. This study emphasizes the importance of intra-canopy processes for biogenic SOA formation in the presence of significant inflow of oxidants as well as anthropogenic aerosols and their precursors.
Acknowledgements. This work was supported by the Japan Society for the Promotion of Science (Grant-in-Aid for JSPS Fellows 2410958 and 24221001) and Grant-in-Aid for Scientific Research (B) (25281002 and 25281010) from the Ministry of Education, Culture, Sports, Science and Technology (MEXT), Japan.

Edited by: A. B. Guenther

\section{References}

Aaltonen, H., Pumpanen, J., Pihlatie, M., Hakola, H., Hellén, H., Kulmala, L., Vesala, T., and Bäck, L.: Boreal pine forest floor biogenic volatile organic compound emissions peak in early summer and autumn, Agric. For. Meteorol., 151, 682-691, 2011.

Atkinson, R. and Arey, J.: Gas-phase tropospheric chemistry of biogenic volatile organic compounds: a review, Atmos. Environ., 37 (Supplement 2), S197-S219, 2003.

Businger, J. A. and Oncley, S. P.: Flux measurement with conditional sampling, J. Atmos. Oceanic Technol., 7, 349-352, 1990.

Calogirou, A., Larsen, B. R., Brussol, C., Duane, M., and Kotzias, D.: Decomposition of terpenes by ozone during sampling on Tenax, Anal. Chem., 68, 1499-1506, 1996.

de Gouw, J. A. and Jimenez, J. L.: Organic Aerosols in the Earth's Atmosphere, Environ. Sci. Technol., 43, 7614-7618, doi:10.1021/es9006004, 2009.

Eddingsaas, N. C., Loza, C. L., Yee, L. D., Chan, M., Schilling, K. A., Chhabra, P. S., Seinfeld, J. H., and Wennberg, P. O.: $\alpha$-pinene photooxidation under controlled chemical conditions - Part 2: SOA yield and composition in low- and high- $\mathrm{NO}_{x}$ environments, Atmos. Chem. Phys., 12, 7413-7427, doi:10.5194/acp-12-74132012, 2012.

Edney, E. O., Kleindienst, T. E., Jaoui, M., Lewandowski, M., Offenberg, J. H., Wang, W., and Claeys, M.: Formation of 2methyltetrols and 2-methylglyceric acid in secondary organic aerosol from laboratory irradiated isoprene/ $\mathrm{NO}_{x} / \mathrm{SO}_{2}$ air mixtures and their detection in ambient $\mathrm{PM}_{2.5}$ samples collected in the eastern United Sates, Atmos. Environ., 39, 5281-5289, 2005.

Ehn, M., Kleist, E., Junninen, H., Petäjä, T., Lönn, G., Schobesberger, S., Dal Maso, M., Trimborn, A., Kulmala, M., Worsnop, D. R., Wahner, A., Wildt, J., and Mentel, Th. F.: Gas phase formation of extremely oxidized pinene reaction products in chamber and ambient air, Atmos. Chem. Phys., 12, 5113-5127, doi:10.5194/acp-12-5113-2012, 2012.

Ehn, M., Thornton, J. A., Kleist, E., Sipilä, M., Junninen, H., Pullinen, I., Springer, M., Rubach, F., Tillmann, R., Lee, B., LopezHilfiker, F., Andres, S., Acir, I. H., Rissanen, M., Jokinen, T., Schobesberger, S., Kangasluoma, J., Kontkanen, J., Nieminen, T., Kurtén, T., Nielsen, L. B., Jørgensen, S., Kjaergaard, H. G., Canagaratna, M., Maso, M. D., Berndt, T., Petäjä, T., Wahner, A., Kerminen, V. M., Kulmala, M., Worsnop, D. R., Wildt, J., and Mentel, T. M.: A large source of low-volatility secondary organic aerosol, Nature Lett., 506, 476-479, doi:10.1038/nature13032, 2014.

Emanuelsson, E. U., Hallquist, M., Kristensen, K., Glasius, M., Bohn, B., Fuchs, H., Kammer, B., Kiendler-Scharr, A., Nehr, S., Rubach, F., Tillmann, R., Wahner, A., Wu, H.-C., and Mentel, Th. F.: Formation of anthropogenic secondary organic aerosol (SOA) 
and its influence on biogenic SOA properties, Atmos. Chem. Phys., 13, 2837-2855, doi:10.5194/acp-13-2837-2013, 2013.

Faiola, C. L., VanderSchelden, G. S., Wen, M., Elloy, F. C., Cobos, D. R., Watts, R. J., Jobson, B. T., and VanReken, T. M.: SOA formation potential of emissions from soil and leaf litter, Environ. Sci. Technol., 48, 938-946, 2014.

Fu, P., Kawamura, K., Chen, J., and Barrie, L. A.: Isoprene, monoterpene, and sesquiterpenes oxidation products in the high arctic aerosols during late winter to early summer, Environ. Sci. Technol., 43, 4022-4028, 2009.

Fuentes, J. D., Wang, D., Bowling, D. R., Potosnal, M., Monson, R. K., Goliff, W. S., and Stockwell, W. R.: Biogenic hydrocarbon chemistry within and above a mixed deciduous forest, J. Atmos. Chem., 56, 165-185, 2007.

Goldstein, A. H., McKay, M., Kurpius, M. R., Schade, G. W., Lee, A., and Holzinger, R.: Forest thinning experiment confirms ozone deposition to forest canopy is dominated by reaction with biogenic VOCs, J. Geophys. Res., 31, L22106, doi:10.1029/2004GL021259, 2004.

Goldstein, A. H., Koven, C. D., Heald, C. L., and Fung, I. Y.: Biogenic carbon and anthropogenic pollutants combine to form a cooling haze over the southeastern United States, P. Natl. Acad. Sci., 106, 8835-8840, doi:10.1073/pnas.0904128106, 2009.

Guenther, A. B., Zimmerman, P. R., and Harley, P. C.: Isoprene and monoterpene emission rate variability: Model evaluations and sensitivity analysis, J. Geophys. Res., 98, 12609-12617, 1993.

Guenther, A. B., Jiang, X., Heald, C. L., Sakulyanontvittaya, T., Duhl, T., Emmons, L. K., and Wang, X.: The Model of Emissions of Gases and Aerosols from Nature version 2.1 (MEGAN2.1): an extended and updated framework for modeling biogenic emissions, Geosci. Model Dev., 5, 1471-1492, doi:10.5194/gmd-51471-2012, 2012.

Hakola, H., Tarvainen, V., Laurila, T., Hiltunen, V., Hellén, H., and Keronen, P.: Seasonal variation of VOC concentrations above a boreal coniferous forest, Atmos. Environ., 37, 1623-1634, 2003.

Hallquist, M., Wenger, J. C., Baltensperger, U., Rudich, Y., Simpson, D., Claeys, M., Dommen, J., Donahue, N. M., George, C., Goldstein, A. H., Hamilton, J. F., Herrmann, H., Hoffmann, T., Iinuma, Y., Jang, M., Jenkin, M. E., Jimenez, J. L., Kiendler-Scharr, A., Maenhaut, W., McFiggans, G., Mentel, Th. F., Monod, A., Prévôt, A. S. H., Seinfeld, J. H., Surratt, J. D., Szmigielski, R., and Wildt, J.: The formation, properties and impact of secondary organic aerosol: current and emerging issues, Atmos. Chem. Phys., 9, 5155-5236, doi:10.5194/acp-9-51552009, 2009.

Hamotani, K., Monji, N., and Yamaguchi, K.: Development of a long-term $\mathrm{CO}_{2}$ flux measurement system using REA method with density correction, J. Agric. Meteorol., 57, 93-99, 2001.

Hayward, S., Muncey, R. J., James, A. E., Halsall, C. J., and Hewitt, C. N.: Monoterpene emissions from soil in a Sitka spruce forest, Atmos. Environ., 35, 4081-4087, 2001.

Holzinger, R., Lee, A., Paw, K. T., and Goldstein, U. A. H.: Observations of oxidation products above a forest imply biogenic emissions of very reactive compounds, Atmos. Chem. Phys., 5, 67-75, doi:10.5194/acp-5-67-2005, 2005.

Isaacman, G., Kreisberg, N., Yee, L., Chan, A., Worton, D., Hering, S., and Goldstein, A. H.: Hourly measurement of the concentration and gas-particle partitioning of oxygenated organic tracers in anbient aerosol: First results from Berkeley, CA and rural
Alabama, paper presented at American Association for Aerosol Research 32nd Annual Conference, Portland, OR, 2013.

Jenkin, M. E., Boyd, A. A., and Lesclaux, R.: Peroxy radical kinetics resulting from the $\mathrm{OH}$-Initiated oxidation of 1,3-butadiene, 2,3-dimethyl-1,3-butadiene and isoprene, J. Atmos. Chem., 29, 267-298, 1998.

Kanakidou, M., Seinfeld, J. H., Pandis, S. N., Barnes, I., Dentener, F. J., Facchini, M. C., Van Dingenen, R., Ervens, B., Nenes, A., Nielsen, C. J., Swietlicki, E., Putaud, J. P., Balkanski, Y., Fuzzi, S., Horth, J., Moortgat, G. K., Winterhalter, R., Myhre, C. E. L., Tsigaridis, K., Vignati, E., Stephanou, E. G., and Wilson, J.: Organic aerosol and global climate modelling: a review, Atmos. Chem. Phys., 5, 1053-1123, doi:10.5194/acp-5-1053-2005, 2005.

Karl, T., Harley, P., Emmons, L., Thornton, B., Guenther, A., Basu, C., Turnipseed, A., and Jardine, K.: Efficient atmospheric cleansing of oxidized organic trace gases by vegetation, Science, 330 , 816, doi:10.1126/science.1192534, 2010.

Kesselmeier, J. and Staudt, M.: Biogenic volatile organic compounds (VOC): An overview on emission, physiology and ecology, J. Atmos. Chem., 33, 23-88, 1999.

Kourtchev, I., Copolovici, L., Claeys, M. and Maenhaut, W.: Characterization of atmospheric aerosols at a forested site in central Europe, Environ. Sci. Technol., 43, 4665-4671, 2009.

Kristensen, K., Enggrob, K. L., King, S. M., Worton, D. R., Platt, S. M., Mortensen, R., Rosenoern, T., Surratt, J. D., Bilde, M., Goldstein, A. H., and Glasius, M.: Formation and occurrence of dimer esters of pinene oxidation products in atmospheric aerosols, Atmos. Chem. Phys., 13, 3763-3776, doi:10.5194/acp-13-37632013, 2013.

Kuhn, U., Rottenberger, S., Biesenthal, T., Wolf, A., Schebeske, G., Ciccioli, P., Brancaleoni, E., Frattoni, M., Tavares, T. M., and Kesselmeier, J.: Seasonal differences in isoprene and lightdependent monoterpene emission by Amazonian tree species, Glob. Change Biol. 10, 663-682, 2004.

Laffineur, Q., Aubinet, M., Schoon, N., Amelynck, C., Müller, J. F., Dewulf, J., Langenhove, H. V., Steppe, K., Šinpraga, M., and Heinesch, B.: Isoprene and monoterpene emissions from a mixed temperate forest, Atmos. Environ., 45, 3157-3168, 2011.

Leff, J. W. and Fierer, N.: Volatile organic compound (VOC) emissions from soil and litter samples, Soil Biol. Biochem., 40, 16291636, 2008.

Lin, C., Owen, S. M., and Peñuelas, J.: Volatile organic compounds in the roots and rhizosphere of Pinus spp., Soil Biol. Biochem., 39, 951-960, 2007.

Lin, Y. H., Budisulistiorini, S. H., Chu, K., Siejack, R. A., Zhang, H., Riva, M., Zhang, Z., Gold, A., Kautzman, K. E., and Surratt, J. D.: Light-absorbing oligomer formation in secondary organic aerosol from reactive uptake of isoprene epoxydiols, Environ. Sci. Technol., 48, 12012-12021, 2014.

Miyazaki, Y., Aggarwal, S. G., Singh, K., Gupta, P. K., and Kawamura, K.: Dicarboxylic acids and water-soluble organic carbon in aerosols in New Delhi, India, in winter: Characteristics and formation processes, J. Geophys. Res., 114, D19206, doi:10.1029/2009JD011790, 2009.

Miyazaki, Y., Jung, J., Fu, P., Mizoguchi, Y., Yamanoi, K., and Kawamura, K.: Evidence of formation of submicrometer water-soluble organic aerosols at a deciduous forest site 
in northern Japan in summer, J. Geophys. Res., 117, D19213, doi:10.1029/2012JD018250, 2012.

Miyazaki, Y., Fu, P. Q., Ono, K., Tachibana, E., and Kawamura, K.: Seasonal cycles of water-soluble organic nitrogen aerosols in a deciduous broadleaf forest in northern Japan, J. Geophys. Res.Atmos., 119, 1440-1454, doi:10.1002/2013JD020713, 2014.

Mochizuki, T., Tani, A., Takahashi, Y., Saigusa, N., and Ueyama, M.: Long-term measurement of terpenoid flux above a Larix kaempferi forest using a relaxed eddy accumulation method, Atmos. Environ., 83, 53-61, 2014.

Müller, L., Reinnig, M.-C., Naumann, K. H., Saathoff, H., Mentel, T. F., Donahue, N. M., and Hoffmann, T.: Formation of 3-methyl1,2,3-butanetricarboxylic acid via gas phase oxidation of pinonic acid - a mass spectrometric study of SOA aging, Atmos. Chem. Phys., 12, 1483-1496, doi:10.5194/acp-12-1483-2012, 2012.

Noe, S. M., Hüve, K., Niinemets, Ü., and Copolovici, L.: Seasonal variation in vertical volatile compounds air concentrations within a remote hemiboreal mixed forest, Atmos. Chem. Phys., 12, 3909-3926, doi:10.5194/acp-12-3909-2012, 2012.

Nozière, B., González, N. J., Borg-Karlson, A.-K., Pei, Y., Redeby, J. P., Krejci, R., Dommen, J., Prevot, A. S. H., and Anthonsen, T.: Atmospheric chemistry in stereo: A new look at secondary organic aerosols from isoprene, Geophys. Res. Lett., 38, L11807, doi:10.1029/2011GL047323, 2011.

Okano, T. and Arase, T.: Biomass measurement of larch forest in Fuji Hokuroku Flux Research Site, in Annual Report of Global Environmental Monitoring H19, Center for Global Change Environmental Research, Natl. Inst. for Environ. Studies, Tukuba, Japan, 16 p., 2007 (in Japanese).

Paatero, P. and Tapper, U.: Positive matrix factorization: A nonnegative factor model with optimal utilization of error estimates of data values, Environmetrics, 5, 111-126, 1994.

Pankow, J. F.: An absorption model of the gas/particle partitioning of organic compounds in the atmosphere, Atmos. Environ., 28, 185-188, 1994.

Paulot, F., Crounse, J. D., Kjaergaard, H. G., Kürten, A., Clair, J. M. St., Seinfeld, J. H., and Wennberg, P. O.: Unexpected epoxide formation in the gas-phase photooxidation of isoprene, Science, 325, 730-733, 2009.

Rinne, J., Hakola, H., Laurila, T., and Tannik, U.: Canopy scale monoterpene emissions of Pinus sylvestris dominated forests, Atmos. Environ., 34, 1099-1107, 2000.

Schobesberger, S., Junninen, H., Bianchi, F., Lönn, G., Ehn, M., Lehtipalo, K., Dommen, J., Ehrhart, S., Ortega, I. K., Franchin, A., Nieminen, T., Riccobono, F., Hutterli, M., Duplissy, J., Almeida, J., Amorim, A., Breitenlechner, M., Downard, A. J., Dunne, E. M., Flagan, R. C., Kajos, M., Keskinen, H., Kirkby, J., Kupc, A., Kürten, A., Kurtén, T., Laaksonen, A., Mathot, S., Onnela, A., Praplan, A. P., Rondo, L., Santos, F. D., Schallhart, S., Schnitzhofer, R., Sipilä, M., Tomé, A., Tsagkogeorgas, G., Vehkamäki, H., Wimmer, D., Baltensperger, U., Carslaw, K. S., Curtius, J., Hansel, A., Petäjä, T., Kulmala, M., Donahue, N. M., and Worsno, D. R.: Molecular understanding of atmospheric particle formation from sulfic acid and large oxidized organic molecules, P. Natl. Acad. Sci. USA, 110, 17223-17228, 2013.
Spanke, J., Rannik, Ü., Forkel, R., Nigge, W., and Hoffmann, T. Emission fluxes and atmospheric degradadation of monoterpenes above a boreal forest: field measurements and modeling, Tellus, 53B, 406-422, 2001.

Surratt, J. D., Lewandowski, M., Offenberg, J. H., Jaoui, M., Kleindienst, T. E., Edney, E. O., and Seinfeld, J. H.: Effect of acidity on secondary organic aerosol formation from isoprene, Environ. Sci. Technol., 41, 5363-5369, 2007.

Surratt, J. D., Chan, A. W. H., Eddingsaas, N. C., Chan, M., Loza, C. L., Kwan, A. J., Hersey, S. P., Flagan, R. C., Wennberg, P. O., and Seinfeld, J. H.: Reactive intermediates revealed in secondary organic aerosol formation from isoprene, P. Natl. Acad. Sci. USA, 107, 6640-6645, 2010.

Szmigielski, R., Surratt, J. D., Gómez-González, G., Van der Veken, P., Kourtchev, I., Vermeylen, R., Blockhuys, F., Jaoui, M., Kleindienst, T. E., Lewandowski, M., and Claeys, M.: 3-Methyl1,2,3-butanetricarboxylic acid: An atmospheric tracer for terpene secondary organic aerosol, Geophys. Res. Lett., 34, L24811, doi:10.1029/2007GL031338, 2007.

Tani, A., Nozoe, S., Aoki, M., and Hewitt, C. N.: Monoterpene fluxes measured above a Japanese red pine forest at Oshiba plateau, Japan, Atmos. Environ., 36, 3391-3402, 2002.

Tani, A., Tobe, S., and Shimizu, S.: Uptake of methacrolein and methyl vinyl ketone by tree saplings and implications for forest atmosphere, Environ. Sci. Technol., 44, 7096-7101, 2010.

Tuazon, E. C. and Atkinson, R.: A product of the gas-phase reaction of isoprene with the $\mathrm{OH}$ radical in the presence of $\mathrm{NO}_{x}$, Int. $\mathrm{J}$. Chem. Kinet., 22, 1221-1236, 1990.

Urakawa, R., Ohte, N., Shibata, H., Tateno, R., Hishi, T., Fukushima, K., Inagaki, Y., Hirai, K., Oda, T., Oyanagi, N., Nakata, M., Toda, H., Tanaka, K., Fukuzawa, K., Watanabe, T., Tokuchi, N., Nakaji, T., Saigusa, N., Yamao, Y., Nakanishi, A., Enoki, T., Ugawa, S., Hayakawa, A., Kotani, A., Kuroiwa, M., and Isobe, K.: Biogeochemical nitrogen properties of forest soils in the Japanese archipelago, Ecol. Res., 30, 1-2, doi:10.1007/s11284-014-1212-8, 2015.

Xu, L., Guo, H., Boyd, C. M., Klein, M., Bougiatioti, A., Cerully, K. M., Hite, J. R., Isaacman-VanWertz, G., Kreisberg, N. M., Knote, C., Olson, K., Koss, A., Goldstein, A. H., Hering, S. V., de Gouw, J., Baumann, K., Lee, S.-H., Nenes, A., Weber, R. J., and Ng, N. L.: Effects of anthropogenic emissions on aerosol formation from isoprene and monoterpenes in the southeastern United States, P. Natl. Acad. Sci. USA, 112, 37-42, 2015.

Yu, J., Cocke III, D. R., Griffin, R. J., Flagan, R. C., and Seinfeld, J. H.: Gasphase ozone oxidation of monoterpenes: Gaseous and particulate products, J. Atmos. Chem., 34, 207-258, 1999. 